\title{
Effect of Price and Promotion on Car Purchase Decisions at PT Encar Daihatsu Lubuklinggau
}

\author{
Supriyanto $^{1)}$, Ronal Aprianto ${ }^{2)}$, Melvin Melisa ${ }^{3)}$ \\ ${ }^{1), 2,3)}$ Universitas Bina Insan Lubuklinggau \\ supriyanto@univbinainsan.ac.id ${ }^{l}$,ronal.gbs@gmail.com²),melvinmelisa@gmail.com ${ }^{3)}$
}

\begin{abstract}
The purpose of this study was to determine the effect of price and promotion on car purchasing decisions at PT Encar Daihatsu, Lubuklinggau City. The population in this study was 138 and the sample was 58 respondents. The data analysis method used is the regression test, correlation coefficient test, $t$ test, determination coefficient test, and F test. Price results (X1) on Purchase Decisions (Y) have a significant effect with tcount of 5.074> t-table value of 1.673 significant $0.000<0.05$. Promotion Results (X2) on Purchase Decisions (Y) have a significant effect with the tcount of $4.499>$ the ttable value of 1.673 significant $0.000<0.05$. Price (X1) and Promotion (X2) on Purchase Decision (Y) have a significant effect with the value of Fcount (27.461)> Ftable (3.18) significant $0.000<0.05$. The conclusion is that Price and Promotion have partial or simultaneous effect on Car Purchase Decisions at PT Encar Daihatsu, Lubuklinggau City.
\end{abstract}

Keywords: Price, Promotion, Purchase Decision

\section{Introductions}

Today's business competition is increasingly dynamic, complex and uncertain, thus spurring company managers to be able to think creatively, innovatively in order to always provide differentiation and advantages for their company compared to its competitors. Companies are required not only to develop good products, offer them at attractive prices, and make them easily accessible to customers who need them.

Facing this situation, the consumer purchasing decision process is influenced by several factors, both external and internal factors, so that in the end consumers will determine the decisionmaking process in purchasing. The consumer's decision to buy products offered by the company cannot be separated from the price given by the company and the type of promotion used by the company itself.

Prices and promotions given by companies and purchasing decisions are closely related to the benefits that will be obtained by the company, because with prices and promotions that meet consumer preferences, consumers will increase so that the company is embedded in the minds of consumers, this of course can benefit the company because consumers can do it. promotion indirectly to family, friends or to other people.

The level of consumer purchasing decisions offered by the company is formed based on experience, advice and prices provided by the company. The development of the business world that cannot be separated from the current competition requires companies to innovate more so that the company can survive in accordance with the times.

PT. Encar Daihatsu is one of the authorized dealers for the South Sumatra region which is engaged in distribution, sales of cars and servicing of four-wheeled vehicles. Data from sales of cars: Ayla X MT, Sirga X MT DLX, Terios R MT DLX, Mini Bus 1.3 D, 1.5 D, GranMax 
PU 1.3S, 1.5S, Gn Xenia R AT 1.5 DLX, Luxio X AT, Sirion D AT. Pt Encar Daihatsu Lubuklinggau, during the period 2018 are as follows.

Tabel 1 Data on Car Vehicle Purchases at PT Encar Daihatsu in 2018

\begin{tabular}{|c|c|c|c|c|c|c|c|c|c|c|c|c|c|c|}
\hline \multirow[t]{2}{*}{ No } & \multirow[t]{2}{*}{ Nama Kendaraan } & \multicolumn{12}{|c|}{ Bulan } & \multirow[t]{2}{*}{ Total } \\
\hline & & 1 & 2 & 3 & 4 & 5 & 6 & 7 & 8 & 9 & 10 & 11 & 12 & \\
\hline 1. & Ayla X MT & 0 & 3 & 0 & 0 & 2 & 0 & 2 & 2 & 0 & 1 & 2 & 3 & 15 \\
\hline 2. & Sirga X MT DLX & 2 & 1 & 3 & 1 & 3 & 3 & 4 & 3 & 5 & 3 & 2 & 5 & 35 \\
\hline 3. & Terios R MT DLX & 4 & 4 & 3 & 3 & 0 & 0 & 0 & 3 & 1 & 1 & 0 & 4 & 23 \\
\hline 4. & Mini Bus 1.3 D, 1.5 D & 0 & 0 & 0 & 0 & 0 & 0 & 2 & 0 & 0 & 1 & 0 & 2 & 5 \\
\hline 5. & GranMax PU 1.3S,1.5S & 3 & 1 & 7 & 0 & 3 & 4 & 0 & 3 & 2 & 4 & 6 & 7 & 40 \\
\hline 6. & Gn Xenia R AT 1.5 DLX & 0 & 2 & 0 & 1 & 3 & 0 & 1 & 4 & 0 & 1 & 0 & 3 & 15 \\
\hline 7. & Luxio X AT & 0 & 0 & 0 & 2 & 0 & 1 & 1 & 0 & 0 & 0 & 1 & 0 & 5 \\
\hline 8. & Sirion D AT & 0 & 0 & 0 & 0 & 0 & 0 & 0 & 0 & 0 & 0 & 0 & 0 & $\mathbf{0}$ \\
\hline & Total & & & & & & & & & & & & & 138 \\
\hline
\end{tabular}

Source PT Encar Daihatsu Lubuklinggau

Based on the table above, it is known that sales of Ayla X MT 15 cars, while sales of Sirga X MT DLX cars have increased by 35 cars, while sales of Terios R MT DLX cars have decreased by 23 cars, while sales of Mini Bus cars are 1.3 D, $1.5 \mathrm{D}$ 5. cars, while sales of GranMax PU $1.3 \mathrm{~S}, 1.5 \mathrm{~S}$ cars increased by 40 cars, sales of Gn Xenia R AT 1.5 DLX cars decreased by 15 cars, while Luxio X AT experienced a decrease of 5 cars, and Sirion D AT car sales were not there at all 0 .

Based on the research survey at the Encar Daihatsu car showroom, Lubuklinggau City, there are several phenomena that occur. The mismatch of the marketed price greatly impacts the purchase decision. Less optimal purchasing decisions are due to inadequate pricing and promotion decisions Regarding the price, there are still employees who make mistakes in the target price offer due to economic conditions and needs that are taken into consideration in determining the price offered to consumers, and there is still a lack of promotion through the media.

\section{Theory Basis and Hypothesis Development}

\subsection{Buying decision}

a. Understanding the purchase decision

Purchase decision as a selection of action from two or more alternative options. In other words, the person making the decision must have one choice from several available alternatives. If someone is faced with two choices, namely buying and not buying, and then he chooses to buy, then he is in a position to make a decision [3]. Then the purchasing decision is an integration process that is used to combine knowledge to evaluate two or more alternative behaviors and choose one of them [4]. Furthermore, it defines a purchasing decision as the selection of an action from two or more alternative choices [5]. From the above understanding, this researcher concludes that the understanding of a purchase decision is that someone who is originally influenced by the environment, culture, family and so on will form an attitude in the individual, then make a purchase.

b. Factors that influence Purchasing Decisions

The factors that influence purchasing decisions are [6]: 1) Strategic location of the seller; 2) Good service; 3) The ability of the sales force; 4) Advertising and promotion; 5) Classification of goods. 


\section{c. Purchasing Decision Indicators}

Purchasing decision indicators are as follows [8]: 1) Confidence in buying; 2) In accordance with desire; 3) Have the desire to repurchase; 4) Consider product quality; 5) Recommend to others.

\subsection{Price}

a. Understanding Price

Price is the third element of the marketing mix and the only element in the marketing mix that generates revenue, while the other elements represent costs [1]. Then the price is all forms of monetary costs sacrificed by consumers to obtain, own, take advantage of a number of combinations of goods and services from a product [9]. Furthermore, price is one of the important variables in marketing, where price can influence customers in making decisions to buy a product, for various reasons [4]. From the above understanding, this study concludes that price is a value that greatly interacts with all other elements in the marketing mix and is a major factor influencing the choice of a buyer.

\section{b. Factors affecting Price}

Factors that affect the price, namely [1]: 1) The amount of money available for promotional; 2) The nature of the market; 3) The nature of the product; 4) The stage of the product's life cycle.

c. Price Indicator

Price indicators are as follows [1]: 1) Pricing based on cost; 2) Pricing based on value; 3) Pricing based on profit targets.

\subsection{Promotion}

\section{a. Definition of Promotion}

Promotion is a form of marketing communication which is a marketing activity that seeks to disseminate information, influence / persuade, and products to be willing to accept, buy, and be loyal to the products offered by the company concerned [2]. Then Stanton (in Abdurrahman) Promotion is one in the marketing mix that is used to provide, persuade, and remind about the company's products [1]. Furthermore, promotion is the process of communicating the marketing mix variables which are very important to implement by companies in marketing products [9]. From the above definition, this study concludes that promotion is one of the marketing mixes used to increase customer value in customer memories.

\section{b. Factors affecting Promotion}

The factors that influence promotion are [9]: 1) Determining goals; 2) Promotion budget; 3) Target market; 4) Product Characteristics; 5) Competition.

c. Promotion Indicator

Promotion indicators, namely [1]: 1) Advertising activities (advertising); 2) personal selling (personal selling); 3) sales promotion; 4) Public relations (public relations); 5) word of mouth marketing; 6) Direct marketing (direct marketing).

\subsection{Hypothesis}


The hypothesis in this study is as follows:

a. It is suspected that there is a significant influence between price on car purchasing decisions at PT. Encar Daihatsu, Lubuklinggau City.

b. It is suspected that there is a significant effect of promotion on car purchase decisions at PT. Encar Daihatsu, Lubuklinggau City.

c. It is suspected that there is a significant influence between price and promotion on purchasing decisions at PT. Encar Daihatsu, Lubuklinggau City

\section{Research Methods}

\subsection{Population and Sample}

Population is a generalization area consisting of objects, subjects that have certain qualities and characteristics that the researcher determines to be studied from then draw conclusions [15]. The population in this study is 138 .

The sample is part of a number of characteristics possessed by the population used for research. If a large population of researchers is not possible to take everything for research, for example because of limited funds, energy, and time, the researcher can use a sample taken from that population [15]. Due to the total population of 138 people, the researchers took or determined the sample using the Slovin formula, as follows: [16]

$$
\begin{aligned}
& \mathrm{n}=\frac{N}{1+N e^{2}} \\
& \text { Where: } \\
& \mathrm{N}=\text { Total Population } \\
& \mathrm{n}=\text { Number of Samples } \\
& \mathrm{e}=\text { Possible Error Rate }(0.012)
\end{aligned}
$$

So:

$$
\begin{aligned}
& \mathrm{n}=\frac{N}{1+N e^{2}} \\
& \mathrm{n}=\frac{138}{1+138(0,01)^{2}} \\
& \mathrm{n}=\frac{138}{1+1.38} \\
& \mathrm{n}=\frac{138}{2.38} \mathrm{n}=57,98 \quad \text { (58 people) }
\end{aligned}
$$

\subsection{Data Analysis Technique}

Data analysis is an activity after data from all respondents or other data sources have been collected. Activities in data analysis are: grouping data based on variables and types of respondents, tabulating data based on the variables studied, performing calculations to answer problem formulations, and performing calculations to test hypotheses that have been proposed [15]. The data analysis used was the regression test, correlation coefficient test, $t$ test, determination coefficient test, and $\mathrm{F}$ test. 


\section{Discussion}

\subsection{Multiple Linear Regression Results}

Table 2 Multiple Linear Regression Test Results

Price (X1) and Promotion (X2) Against Purchasing Decisions (Y)

\begin{tabular}{|l|r|r|r|}
\hline \multirow{2}{*}{ Model } & \multicolumn{2}{|c|}{ Unstandardized Coefficients } & \multicolumn{2}{c|}{ Standardized Coefficients } \\
\cline { 2 - 4 } & \multicolumn{1}{|c|}{ B } & \multicolumn{1}{|c|}{ Std. Error } & Beta \\
\hline (Constant) & 20,311 & 5,417 & \\
Harga &, 551 &, 109 &, 543 \\
Promosi &, 233 &, 093 &, 268 \\
\hline
\end{tabular}

Source: Results of Multiple Linear Regression Test Data Processing with SPSS 22

Based on the table above shows that the multiple regression equation model for estimating Purchasing Decisions which are influenced by prices and promotions are:

$$
\begin{gathered}
\mathrm{Y}=\mathrm{a}+\mathrm{b} 1 \mathrm{X} 1+\mathrm{b} 2 \mathrm{X} 2 \\
\mathrm{Y}=20.311+0.551+0.233
\end{gathered}
$$

From the above equation that the purchase decision, if there is no price and promotion (X1 and $\mathrm{X} 2=0$ ), then the value of the purchasing decision variable is 20.311. Meanwhile, if the value of the promotion variable increases by one unit. Then the value of the purchase decision will have a positive effect of 0.551 . And if the value of the promotion variable increases by one unit, then the value of the purchase decision will have a positive effect of 0.233 .

\subsection{Correlation Coefficient Results}

Table 3 Correlation Coefficient Test Results

Price (X1) Against Purchase Decision (Y)

\begin{tabular}{|l|l|r|r|r|}
\hline Model & $\mathrm{R}$ & R Square & Adjusted R Square & Std. Error of the Estimate \\
\hline 1 &, $665^{\mathrm{a}}$ &, 443 &, 433 & 3,516 \\
\hline
\end{tabular}

Source: Data Processing Results Correlation Coefficient X1 Against Y with SPSS 22

From the table above, the $\mathrm{R}$ number is 0.665 . This shows that the variable Price (X1) to Performance $(\mathrm{Y})$ has a strong variable relationship. While the direction of the relationship is positive because the value of $\mathrm{R}$ is positive.

Table 4 Correlation Coefficient Test Results

Promotion (X2) Against Purchase Decisions (Y)

\begin{tabular}{|l|l|r|r|r|}
\hline Model & $\mathrm{R}$ & $R$ Square & Adjusted $R$ Square & Std. Error of the Estimate \\
\hline 1 &, $515^{\mathrm{a}}$ &, 265 &, 252 & 4,037 \\
\hline
\end{tabular}

Source: Data Processing Results Correlation Coefficient X2 Against Y with SPSS 22

From the table above, the $\mathrm{R}$ number is 0.515 . This shows that the variable Promotion (X2) Against Purchase Decisions (Y) has a fairly strong variable relationship. While the direction of the relationship is positive because the value of $\mathrm{R}$ is positive. 


\subsection{Result of Determination Coefficient}

Table 5 Determination Coefficient Test Results

Price (X1) and Promotion (X2) Against Purchasing Decisions (Y)

\begin{tabular}{|l|c|r|r|r|}
\hline Model & $\mathrm{R}$ & $R$ Square & Adjusted R quare & \multicolumn{1}{|c|}{ Std. Error of the Estimate } \\
\hline 1 &, $707^{\mathrm{a}}$ &, 500 &, 481 & 3,362 \\
\hline
\end{tabular}

Sumber: Hasil Pengolahan Data Koefesien Determinasi dengan SPSS

From the calculation of the coefficient of determination above, the coefficient of determination is $\mathrm{R}=0.500$ or $50.0 \%$, which means that the relationship between Price (X1) and Promotion (X2) to Purchase Decision (Y) is 50.0\%, while the remaining $50 \%(100 \%-50 \%)$ is influenced by other variables not observed in this study.

\subsection{T Test Results}

Table $6 \mathrm{t}$ test results

Price (X1) Against Purchase Decision (Y)

\begin{tabular}{|l|l|c|c|}
\hline \multicolumn{2}{|l|}{ Model } & $\mathrm{t}$ & Sig. \\
\hline \multirow{2}{*}{1} & $($ Constant $)$ & 3,750 &, 000 \\
\cline { 2 - 4 } & Harga & 5,074 &, 000 \\
\hline
\end{tabular}

Source: Results of t-test data processing against Y with SPSS 22.

Based on the table above, it shows that the tcount results in 5.074. With a total sample size of 58 , it was found that $\mathrm{df}=58(58-2)$ and at the significance level of 0.05 , the t-table value was 1.673. With these results it can be said that the value of the coefficient and tcount is positive so that the price affects the purchase decision.

Table $7 \mathrm{t}$ test results

Promotion (X2) Against Purchase Decisions (Y)

\begin{tabular}{|l|l|c|c|}
\hline \multicolumn{2}{|l|}{ Model } & $\mathrm{t}$ & Sig. \\
\hline \multirow{2}{*}{1} & $($ Constant $)$ & 3,835 &, 000 \\
\cline { 2 - 4 } & Harga & 4,499 &, 000 \\
\hline
\end{tabular}

Source: Results of $\mathrm{t}$ X2 test data processing against $\mathrm{Y}$ with SPSS 22.

Based on the table above, it shows that tcount yields 4,499. With a total sample size of 58 , it was found that $\mathrm{df}=58(58-2)$ and at the significance level of 0.05 , the t-table value was 1.673 . With these results it can be said that the value of the coefficient and tcount is positive so that Promotion affects the Purchasing Decision.

\subsection{F Test Results}

Table 8 F Test Results

Price (X1) and Promotion (X2) Against Purchasing Decisions (Y)

\begin{tabular}{|c|c|c|c|c|c|}
\hline Model & Sum of Squares & Df & Mean Square & $\mathrm{F}$ & Sig. \\
\hline 1 Regression & 620,673 & 2 & 310,337 & 27,461 &, $000^{\mathrm{b}}$ \\
\hline Residual & 621,551 & 55 & 11,301 & & \\
\hline Total & 1242,224 & 57 & & & \\
\hline
\end{tabular}

Source: Results of F Test Data Processing with SPSS 22.

Based on the table above, the Fcount value obtained is 27.461 with a significance level of 0.000 . Where if Fcount $>$ Ftable then Ho is rejected and Ha is accepted. Conversely, if Fcount $<$ Ftable 
then Ho is accepted and Ha is rejected. In this study, it turns out that Fcount (27.461)> Ftable (3.18), meaning that Ho is rejected and Ha is accepted. This shows that there is a significant influence between the Price variable (X1) and the Promotion variable (X2) on the Purchasing Decision (Y).

\section{Conclusion}

Based on research from the analysis in accordance with the formulation of the research problem, the researcher can conclude that:

a. Price (X1) has a significant effect on Purchase Decision (Y) with the results of the t-test calculation showing the t-count value of 5.074> the $t$-table value of 1.673 with a significant $0.000<0.05$.

b. Promotion (X2) has a significant effect on Purchase Decision (Y) with the results of the ttest calculation showing the $t$-count value of $4.499>$ the $t$-table value of 1.673 with a significant $0.000<0.05$.

c. Price (X1) and Promotion (X2) have a significant effect on Purchase Decisions (Y) with the results of the $F$ test calculation showing the value of Fcount (27.461)> Ftable (3.18) with a significant $0.000<0.05$.

\section{Suggestion}

From the results of the conclusions that have been drawn previously, several suggestions can be made as follows:

a. Companies should set prices that are affordable to middle-class communities.

b. Companies should further increase promotion through social media and must provide attractive discounts for consumers so that consumers are not interested in buying other dealers.

c. Companies should provide training for sales to better understand the products to be offered to consumers, so that consumers are sure to buy the products offered.

\section{References}

Hana Herdiana Abdurrahman, manajemen strategi pemasaran. bandung, 2015.

R. Hurriyati, bauran pemasaran dan loyalitas konsumen. bandung: Alfabeta, 2018.

Sudaryono, manajemen pemasaran teori dan implementasi, 1st ed. yogyakarta: Andi, 2016.

P. K. Prod et al., "ISSN 2303-1174 C.J.Gerung., J.Sepang., S.Loindong. Pengaruh Kualiatas Prod ............," J. Emba, vol. 5, no. 2, pp. 2221-2229, 2017.

S. Zulaicha, R. Irawati, P. Administrasi, B. Terapan, and P. N. Batam, "PEMBELIAN KONSUMEN DI MORNING BAKERY," J. Inov. dan bisnis, vol. 4, pp. 2338-4840, 2016.

D. Agusra, "Pengaruh Produk Dan Harga Terhadap Keputusan Pembelian Tepung Bumbu Mamasuka," J. Econ. Bus. Accouning, vol. 2, pp. 2597-5234, 2018.

Setiyaningrum, Ari, “Prinsip-Prinsip PEMASARAN,” Jogyakarta: Andi, 2015.

D. Kurniawan and E. Widajanti, "Pengaruh Promosi Dan Harga Terhadap Keputusan Pembelian Rokok Djarum Super Dengan Kepuasan Konsumen Sebagai Variabel Moderasi," J. Ekon. dan Kewirausahaan, vol. 15, no. 3, pp. 354-366, 2015.

A. Hasan, marketing dan kasus-kasus pilihan. jogyakarta: CAPS, 2013. 
Nst muhammad fakru rizky, Hanifa Yasin. Pengaruh Promosi Dan Harga Terhadap Minat Beli Perumahan Obama PT. Nailah Adi Kurnia Sei Mencirim Medan. Manaj dan Bisnis. 2014;14:1693-7619.

I. Yuliana and Jonson, "Pengaruh Harga Dan Promosi Terhadap Keputusan Pembelian Pada PT. Zuvace Mondy Di Kota Batam,” J. Akunt. dan Bisnis, vol. 2, 2017.

Akrim Ashal Lubis, "Pengaruh Harga Dan Kualitas Produk Terhadap Keputusan Pembelian Surat Kabar Pada PT. Suara Barisan Hijau harian Orbit Medan," J. Ilm. Manaj. dan Bisnis, vol. 16, no. 2, pp. 1-11, 2015.

E. S. Imaningsih, “THE MODEL OF PRODUCT QUALITY, PROMOTION , PRICE, AND PURCHASE DECISIONS,” vol. XXIII, no. 2, pp. 260-271, 2018.

prof D. Sugiono, Metode Penelitian Kualitatif Kuantitatif dan R\&D. bandung: Alfabeta, 2019.

P. D. Sugiyono, Metode Penelitian Kualitatif Kuantitatif dan R\&D. bandung: Alfabeta, 2015.

S. Siregar, Statistik Parametrik untuk Penelitian Kuantitatif. Jakarta: PT BUMI AKSARA, 2013.

W.Sujarweni, Metodologi Penelitian Bisnis \& Ekonomi. Ke-1. Yogyakarta: PUSTAKA BARU PRESS; 2015. 